\title{
Low Tech Biochar Production Could Be a Highly Effective Nature-Based Solution for Climate Change Mitigation in the Developing World.
}

brenton ladd ( $\sim$ bladd@cientifica.edu.pe)

Universidad Científica del Sur https://orcid.org/0000-0002-9388-6298

Camila Aquije

Universidad Científica del Sur

Hans-Peter Schmidt

Ithaka Institute for Carbon Strategies

Kathleen Draper

Ithaka Institute for Carbon Intelligence

Stephen Joseph

University of New South Wales

\section{Research Article}

Keywords: biochar, compost, landfill, municipal green waste, climate change mitigation, carbon footprint

Posted Date: May 20th, 2021

DOl: https://doi.org/10.21203/rs.3.rs-518620/v1

License: (c) (i) This work is licensed under a Creative Commons Attribution 4.0 International License. Read Full License 


\section{Abstract}

Aim

To compare the climate change mitigation benefits of nature-based solutions for management of municipal green waste with conventional management.

\section{Methods}

This study analyzed the carbon footprint of managing one ton of municipal green waste (MGW) in Lima Peru under 4 different scenarios: 1) Final disposal in authorized landfill, 2) Final disposal in informal landfill, 3) composting and 4) biochar production using a low-cost low tech Kon-Tiki reactor.

Results

The results demonstrate the very clear potential for climate change mitigation from biochar production using low tech and therefore accessible technology in a typical developing world context. The carbon footprint of producing biochar was lower than for composting and biochar and compost both had carbon footprints significantly lower than waste management achieved via landfilling.

\section{Conclusion}

We argue that the standards used by nascent platforms for trading carbon removal credits generated by biochar should be expanded to include small scale market participants in the so-called developing world. Waste management in the developing world presents significant challenges but often starts from a very low base which means there is very large potential for reducing emissions as well as sequestering carbon.

\section{Introduction}

It is now clear that the production and use of biochar in agriculture and soil remediation has a clear economic value proposition (Thomas et al. 2020; Ladd et al. 2018). At the same time there is growing awareness among scientists and decision makers that simply curtailing greenhouse gas (GHG) emissions will be insufficient to avert a climate crisis (Ravi et al. 2016; Li et al. 2019; Rogelj et al. 2021). The level of carbon pollution in the earth's atmosphere has reached a level where humanity must increase investment in technologies and strategies that generate negative emissions, i.e., which actually draw down the level of carbon dioxide in the atmosphere (Alcalde et al. 2018; Mulligan et al. 2020; EBIC 2021). The possibilities for doing this are surprisingly limited (Schlesinger 2020). Nevertheless, it is clear that biochar production and use is one such ready to implement technology / land management strategy that could generate significant amounts of negative emissions. For this reason, we are now seeing the development of trading platforms for the buying and selling of carbon credits for the negative emissions generated with biochar, i.e., Puro (2021) and Carbonfuture (2021). 
Whilst such positive developments are to be welcomed, there is need for refinement of the general approach so that it is more inclusive and doesn't exclude, by design, participation from actors in the developing world. The above-mentioned trading platforms and standards tend to place an emphasis on using state-of-the-art technology for biochar production to minimize emissions during the process. This is perfectly reasonable and doable in a developed world context, were effective and advanced waste management systems and legislation are already in place. In the developing world, waste management often starts from a much lower base. Further, the generation of organic waste (or "biological" to differentiate from the label "organic") is highly heterogenous. At points of aggregation for crops like coffee and cacao volumes of waste are small and seasonal. In these contexts, the requirement for significant upfront investment in state-of-the-art technology may act as a barrier to participation.

The criteria for whether a project achieves negative emissions should ideally be anchored in something like the concept of additionality developed by the UN for REDD. For example, In Lima a mega city on the Peruvian coast, we see the generation of 2,500 tonnes of municipal green waste per month. Only a small fraction of this is composted. In Lima in 2014 a total of 7.5 million metric tons of urban solid waste was generated; $47 \%$ of the waste ended up in informal (illegal) landfills and only $21 \%$ was sent to licenced landfills (Ziegler et al. 2018). For both formal and informal landfills green waste decomposes in an anoxic environment, liberating potent greenhouse gases such as methane and nitrous oxide (Eklund et al. 1998). In this context the production of biochar from municipal green waste in an artisanal biochar reactor such as a Kon-tiki Kiln (Ithika 2021) could be considered a significant improvement over the status quo. Here we calculate the carbon footprint of municipal green waste management using four different strategies: 1) final disposition in a licenced landfill, 2) final disposition in an informal landfill, 3) composting, and 4) biochar production using low cost, artisanal technology.

\section{Materials And Methods}

Using one ton of Municipal Green Waste (MGW) as the unit of analysis we calculated the carbon footprint of managing municipal green waste in Lima, Peru under four different scenarios: 1) business as usual (final disposition in licensed landfills), 2) business as usual (final disposition in unlicensed landfills), 3) the production of compost and 4) the production of biochar using a Kon-Tiki reactor. In all four cases we assume that the plant biomass carbon content is 50\% following IPCC (2014).

In all four scenarios the first significant emission of GHG comes from transportation of biomass. Lima is a megacity and transport distances vary depending on proximity to the urban core. Nevertheless, transport associated emissions are inevitable because landfill sites are located on the outskirts of the city, just beyond city limits where the impact of waste management on residents is reduced. The informal landfills are even further from the urban core. Using the specific example of MGW from the municipality of Lurin on Lima's southern fringe we assume the emission of $340 \mathrm{~g}$ of $\mathrm{CO}_{2}$ emitted per ton of municipal green waste per km in a medium sized truck (Seo et al. 2016). In this specific case changing from landfilling to either composting or biochar production reduces transport emissions (Table 1) because the biochar /compost plant is closer to the urban core than the landfill sites (Appendix s1). 
Table 1

Calculation of carbon footprint using 4 different strategies for management of municipal green waste. A multiplier of 25 was used to convert methane into $\mathrm{CO}_{2}$ eq.

\begin{tabular}{|c|c|c|c|c|}
\hline & $\begin{array}{l}\text { Licensed } \\
\text { Landfill }\end{array}$ & $\begin{array}{l}\text { Informal } \\
\text { Landfill }\end{array}$ & $\begin{array}{l}\text { Compost } \\
\text { (Windrow) }\end{array}$ & $\begin{array}{l}\text { Biochar } \\
\text { (Kon-Tiki) }\end{array}$ \\
\hline green waste $(\mathrm{kg})$ & 1000 & 1000 & 1000 & 1000 \\
\hline carbon content of $1000 \mathrm{~kg}$ green waste & 500 & 500 & 500 & 500 \\
\hline biomass transport emissions & 2.47 & 2.47 & 0.83 & 0.83 \\
\hline $\begin{array}{l}\mathrm{Kg} \text { of } \mathrm{C} \text { embodied in compost or biochar after } \\
\text { processing }\end{array}$ & - & - & 240.00 & 150.00 \\
\hline $\begin{array}{l}\text { Kg of C liberated as GHG during composting or } \\
\text { biochar production }\end{array}$ & - & - & 260.00 & 350.00 \\
\hline $\begin{array}{l}\mathrm{Kg} \text { of } \mathrm{C} \text { liberated as GHG when pumping ground } \\
\text { water for composting }\end{array}$ & - & - & 0.01 & - \\
\hline $\begin{array}{l}\mathrm{Kg} \text { of } \mathrm{C} \text { liberated as } \mathrm{GHG} \text { to fabricate the metal } \\
\text { needed to build a Kon-Tiki oven }\end{array}$ & - & - & - & 0.37 \\
\hline $\mathrm{CO}_{2}$ emissions from waste treatment strategy & - & - & 243.75 & 334.53 \\
\hline $\begin{array}{l}\mathrm{CH}_{4} \text { emissions from waste treatment strategy } \\
\left(\mathrm{CO}_{2} \text { eq }\right)\end{array}$ & - & - & 406.25 & 46.25 \\
\hline $\begin{array}{l}\text { Subtotal emissions from waste treatment } \\
\text { strategy }\end{array}$ & 1359.00 & 1497 & 650 & 380.78 \\
\hline TOTAL (kg CO2-eq.) & 1361.47 & 1499.47 & 650.84 & 381.98 \\
\hline
\end{tabular}

The step after transporting is the processing of the waste. In the first and seconds scenarios, in which MGW is disposed of in formal and informal landfills there are many uncertainties around the amount of GHG released from the relevant biomass. Nevertheless, values are likely high since the anoxic conditions found at landfill sites favor the liberation of potent GHGs such as methane and nitrous oxides (Eklund et al. 1998). For the specific case of landfill on the hyper arid Peruvian coast, we have an already a completed life cycle analysis applicable to both formal and informal landfills (Ziegler et al. 2019).

In the third scenario, in which the MGW is composted, we assume that $52 \%$ of the $\mathrm{C}$ contained in the waste biomass is retained in the compost, after Tiquia et al. (2002). For the remaining $48 \% \mathrm{C}$ we assume $3 \%$ is lost as methane and $45 \%$ is liberated as $\mathrm{CO}_{2}$, based on Boldrin et al. (2009). For the production of compost, we also calculate the emissions that result from pumping the ground water needed for the composting process. Ideally compost should be $60 \%$ water by weight. We assume composting takes place over 60 days. In Lima the rate of evaporation of $952.9 \mathrm{~mm}$ per annum (MIDAGRI, n.d.). Thus, an area of $2 \mathrm{~m}^{2}$, i.e., the area that $1000 \mathrm{~kg}$ of MGW would occupy, would require 317.6 liters of water for optimal composting. In Lurin ground water is used and obtained using a 1 horsepower pump. This in turn 
requires $32.9 \mathrm{~W}$ of electricity which results in $0.013 \mathrm{~kg}$ of $\mathrm{CO}_{2}$ equivalent from the electricity used to pump water per ton of MGW composted.

Finally, for the scenario in which MGW is used to produce biochar we assume that $30 \%$ of the C contained in the feedstock biomass is retained in the biochar produced, after Mohammadi et al. (2016). For the $70 \%$ of the $\mathrm{C}$ content of the feedstock which is lost during the production process, we assume that $96 \%$ is liberated to the atmosphere in the form of $\mathrm{CO}_{2}$, and $.05 \%$ in the form of methane, based on the measurements of Cornelissen et al. (2016). Finally, we calculated the emissions embodied in metal used to manufacture a Kontiki oven. For every ton of steel produced we assume that 1.85 tons of $\mathrm{CO}_{2}$ are emitted (Hoffmann et al. 2020). A Kon-Tiki kiln uses $200 \mathrm{~kg}$ of metal thus resulting in the emission 0.37 $\mathrm{kg} \mathrm{CO}_{2}$. Every kiln has a life cycle of roughly 300 burns and each individual burn produces around $320 \mathrm{~kg}$ of biochar. The $0.37 \mathrm{~kg} \mathrm{CO}_{2}$ embodied in the steel used to fabricate a Kontiki oven was distributed across the biochar produced across the 300 burns just mentioned resulting in an insignificant level of emissions (Table 1).

\section{Results}

The analysis of the carbon footprint across the 4 alternative strategies for managing MGW suggests that biochar should be the preferred treatment method, followed by composting, followed by final disposition in licensed or unlicensed landfills (Table 1). If we extend the time frame of the carbon foot print analysis and consider the fate of the carbon contained in either compost or biochar once added to soil then a slightly different picture emerges. The half-life of compost can be as low as 45 days (Araújo et al. 2020). Biochar on the other hand may persist in soil over millennial time scales (Spokas 2010), and may even favour the accumulation of new non-pyrogenic soil carbon (Weng et al. 2017). Thus, if we extend the carbon footprint analysis to 45 days after the compost or biochar has been incorporated into soil then an additional $130 \mathrm{~kg}$ of $\mathrm{CO}_{2} \mathrm{e}$ will be liberated to the atmosphere from compost. The corresponding figure for biochar is likely to be insignificant and the carbon footprint of biochar is thus likely significantly improved relative to compost. However, in a real-world context both composting and biochar production are synergistic for management of MGW. MGW is heterogenous. It contains certain components (lawn clipping, leaves) that are easy to compost and complicated to pyrolyze and a woody component that is difficult to compost but relatively easy to pyrolyze (Fig. 1).

\section{Discussion}

Governance over waste management practices in developing nations such as Peru is far from optimal. If heavy investment in state-of-the-art technology is required before biochar production becomes eligible for carbon credits, then very likely it will remain business as usual with the continuation of high rates of GHG emission from poorly managed landfills. We think the nascent standards for carbon removals from biochar should expand the technology requirement to favor participation by actors in developing world contexts. The calculations in Table 1 demonstrate that every ton of MGW diverted from landfill to 
artisanal biochar production decreases $\mathrm{CO}_{2}$ eq emissions to the atmosphere by one ton. Extrapolating to the amount of MGW produced each month in Lima, we arrive at a figure of 2500 tons $\mathrm{CO}_{2}$ eq emissions mitigated per month. If we then consider waste management in all the other megacities in the developing world where waste management likely starts from the same low base the potential for climate change mitigation begins to look promising. The development of the nascent trading platforms for negative emissions generated by biochar are a welcome development. However, the general framework needs to be more inclusive. Allowing lower cost production via artisanal technology could potentially facilitate participation from actors in the developing world and this in turn could promote a large amount of climate change mitigation.

\section{Declarations}

\section{Acknowledgements}

The authors would like to thank the following people who contributed to the article by commenting on the first drafts:

\section{Funding}

Seed funding from the research office at the Universidad Cientifica del Sur (grant 027-2021-PRO99) is gratefully acknowledged.

\section{Conflict of interest}

The authors declare no conflicts of interest.

\section{References}

Alcalde J, Smith, P, Haszeldine RS, Bond CE (2018) The potential for implementation of Negative Emission Technologies in Scotland. International Journal of Greenhouse Gas Control 76: 85-91. https://doi.org/10.1016/j.ijggc.2018.06.021

Araújo M, Feitosa M, Primo A, Taniguchi C, Souza H (2020) Mineralization of nitrogen and carbon from organic compost from animal production waste. Revista Caatinga 33(2): 310-320.

https://doi.org/10.1590/1983-21252020v33n204rc

Boldrin A, Andersen JK, Møller J, Christensen TH, Favoino E (2009). Composting and compost utilization: accounting of greenhouse gases and global warming contributions. Waste Management \& Research 27(8): 800-812. https://doi.org/10.1177/0734242X09345275

Carbonfuture (2021) https://carbonfuture.earth/. Accessed 5/5/21. 
Cornelissen G, Pandit NR, Taylor P, Pandit BH, Sparrevik M, Schmidt HP (2016) Emissions and char quality of flame-curtain" Kon Tiki" Kilns for Farmer-Scale charcoal/biochar production. PloS one: 11(5), e0154617. https://doi.org/10.1371/journal.pone.0154617

EBIC (2021). https://www.biochar-industry.com/why/, accessed 5/5/21.

Eklund B, Anderson EP, Walker BL, Burrows DB (1998) Characterization of landfill gas composition at the fresh kills municipal solid-waste landfill. Environmental Science \& Technology 32(15): 2233-2237. https://doi.org/10.1021/es980004s

Hoffmann C, Van Hoey M, Zeumer B (2020) Decarbonization challenge for Steel. McKinsey \& Company. https://www.mckinsey.com/industries/metals-and-mining/our-insights/decarbonization-challenge-forsteel\# Accessed 04 April 2021.

IPCC (2014) Climate Change 2014: Synthesis Report. Contribution of Working Groups I, II and III to the Fifth Assessment Report of the Intergovernmental Panel on Climate Change [Core Writing Team, R.K. Pachauri and L.A. Meyer (eds.)]. IPCC, Geneva, Switzerland, 151 pp.

Ithaka (2021) https://www.pinterest.com/ithakainstitute/kon-tiki-kiln/. Accessed 5/5/21.

Ladd B, Dumler S, Loret de Mola E, Anaya de la Rosa R, Borchard N (2018) Incremento de rentabilidad en producción del maíz en Perú: nfertilizantes y biochar. The Biologist 15(2). https://doi.org/10.24039/rtb201715294

Li L, Yao Z, You S, Wang CH, Chong C, Wang X (2019) Optimal design of negative emission hybrid renewable energy systems with biochar production. Applied energy 243: 233-249.

https://doi.org/10.1016/j.apenergy.2019.03.183

MIDAGRI (n.d.). Evaporación. Ministerio de Desarrollo Agrario y Riego.

https://www.midagri.gob.pe/portal/53-sector-agrario/el-clima/369-principales-variables-climaticas-de-lacosta\#. Accessed 5/5/21.

Mohammadi A, Cowie A, Mai T, Anaya de la Rosa R, Kristiansen P, Brandao M, Joseph S (2016) Biochar use for climate-change mitigation in rice cropping systems. Journal of cleaner production: 116, 61-70. https://doi.org/10.1016/j.jclepro.2015.12.083

Mullingan J, Ellison G, Levin K, Lebling K, Rudee A (2020). 6 ways to remove carbon poluttion from the sky. World Resources Institute. https://www.wri.org/insights/6-ways-remove-carbon-pollution-sky. Accessed 5/5/21.

Puro (2021). https://puro.earth/. Accessed 5/5/21.

Ravi S, Sharratt B, Li J, Olshevski S, Meng Z, Zhang J (2016) Particulate matter emissions from biocharamended soils as a potential tradeoff to the negative emission potential. Scientific reports 6(1): 1-7. 
Rogelj J, Geden O, Cowie A, Reisinger A (2021) Net-zero emissions targets are vague: three ways to fix. Nature 591: 365-368. https://www.nature.com/articles/d41586-021-00662-3.

Seo J, Park J, Oh Y, Park S (2016) Estimation of total transport $\mathrm{CO}_{2}$ emissions generated by medium-and heavy-duty vehicles (MHDVs) in a sector of Korea. Energies 9(8): 638.

https://doi.org/10.3390/en9080638

Schlesinger W (2020) http://ieg4.rccc.ou.edu/seminar/video/4458622e-83e9-4aa6-baead98deb6dab7e.html. Accessed 5/5/21.

Spokas KA (2010) Review of the stability of biochar in soils: predictability of O: C molar ratios. Carbon Management, 1(2): 289-303. https://doi.org/10.4155/cmt.10.32

Thomas E, Borchard N, Sarmiento C, Atkinson R, Ladd B (2020) Key factors determining biochar sorption capacity for metal contaminants: a literature synthesis. Biochar 2: 151-163.

https://doi.org/10.1007/s42773-020-00053-3

Tiquia SM, Richard TL, Honeyman MS (2002) Carbon, nutrient, and mass loss during composting. Nutrient Cycling in Agroecosystems: 62(1), 15-24. https://doi.org/10.1023/A:1015137922816

Weng ZH, Van Zwieten L, Singh BP, Tavakkoli E, Joseph S, Macdonald LM, Rose TJ, Rose MT, Kimber SW, Morris S, Cozzolino D (2017) Biochar built soil carbon over a decade by stabilizing rhizodeposits. Nature Climate Change, 7(5), 371-376.

Zhu-Barker X, Bailey SK, Burger M, Horwath WR (2016) Greenhouse gas emissions from green waste composting windrow. Waste management 59: 70-79. https://doi.org/10.1016/j.wasman.2016.10.004

Ziegler K, Margallo M, Aldaco R, Irabien J, Vázquez I, Kahhat R (2018) Environmental performance of peruvian waste management systems under a life cycle approach. Chemical Engineering Transactions, 70: 1753-1758. doi: 10.3303/CET1870293

Ziegler K, Vázquez-Rowe I, Kahhat R, Margallo M (2019) Proyecto IKI-PNUMA. Avanzando y midiendo consumo y producción sostenible para una economía baja en carbono en economías de ingresos medios y nuevos países industrializados en Perú. Actividad 9: Rellenos Sanitarios. Pontificia Universidad Católica del Perú. http://perulca.com/wp-content/uploads/2019/04/documento_c.pdf. Accessed 5/5/21.

\section{Figures}




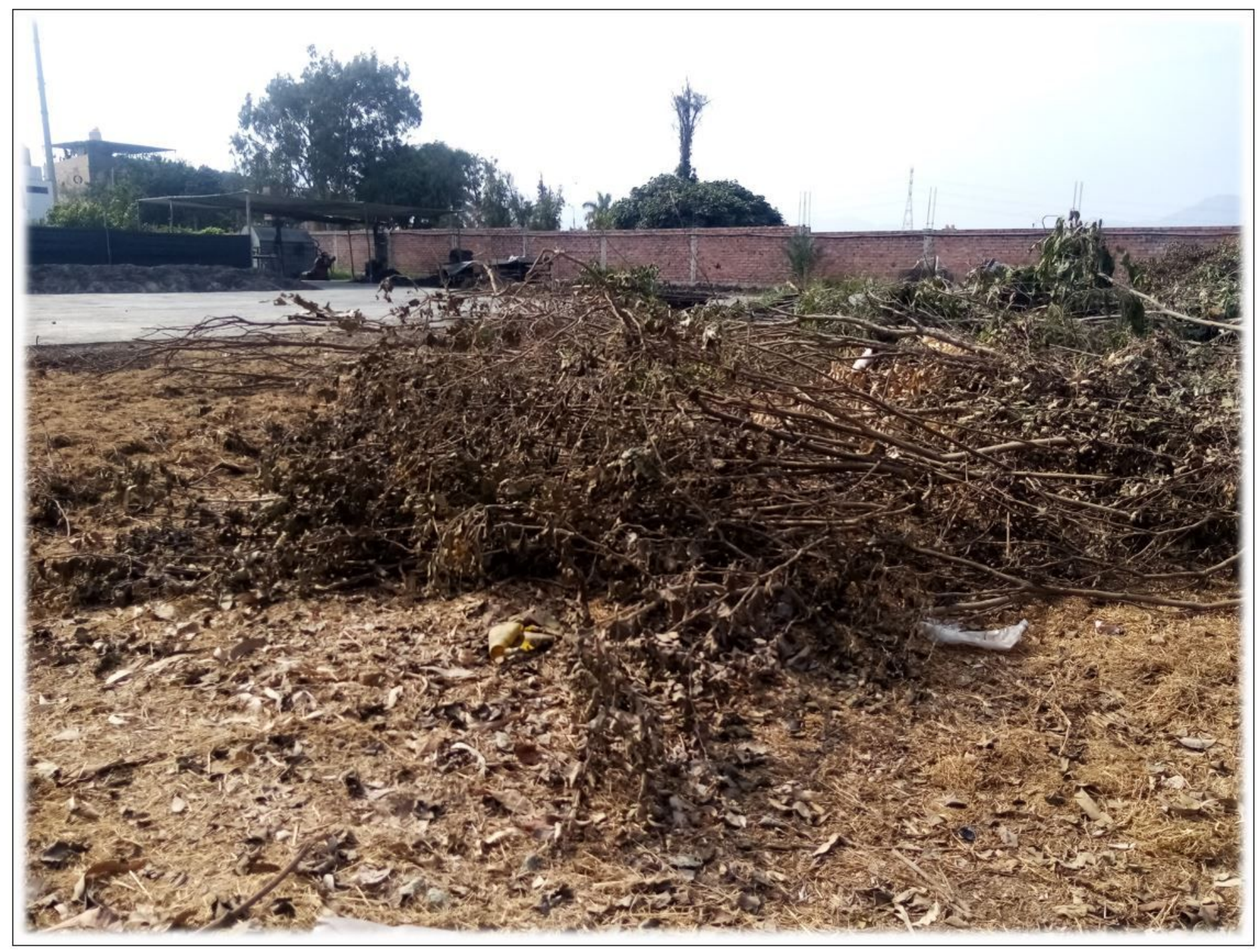

Figure 1

Municipal green waste is a heterogenous mixture that includes components (cut grass) for which composting is an ideal waste management strategy. There is also a woody component obtained via pruning trees and shrubs that would require additional processing (chipping) before composting becomes a viable strategy. The woody component is also likely to contain a high lignin content which will increase the time, cost and emissions of composting.

\section{Supplementary Files}

This is a list of supplementary files associated with this preprint. Click to download.

- appendixs1.pdf 